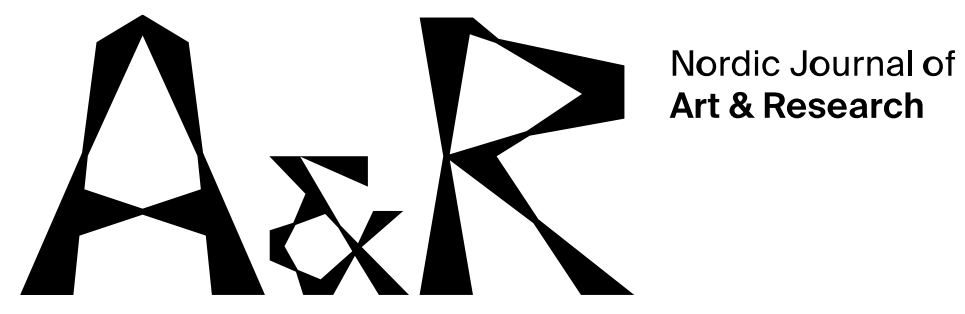

\title{
Renegotiating Aesthetic Disinterest for the Literature Classroom
}

\author{
Mildrid H. A. Bjerke ${ }^{1}$ \\ Oslo Metropolitan University
}

\begin{abstract}
This paper discusses an ideological conflict between a so-called disinterested appreciation of literature and what I refer to as the 'neoliberal ethos'. I am interested, primarily, in the influence of this tension on literary pedagogy. I will argue that the way in which the neoliberal ethos has permeated educational settings creates a need for a reconceptualised notion of aesthetic disinterest, without which we will struggle to coherently argue for alternative conceptions of the value of education, especially arts and humanities education. I hope to show that reviving the concept of disinterest will facilitate a renegotiation of the literature classroom as a space for genuine aesthetic experience and non-instrumental discussion.
\end{abstract}

Keywords: aesthetic disinterest, aesthetic education, aesthetic experience, literary pedagogy, arts and humanities and neoliberalism, humanities debate, neoliberal education, instrumentalism

\section{Introduction}

This paper discusses an ideological conflict between a so-called 'disinterested' appreciation of literature and what I refer to as the 'neoliberal ethos'. The conception of neoliberal ideology qua an ethos seeks to describe the way in which neoliberalism, in addition to operating top-down through governmental and managerial policies, is

${ }^{1}$ milbje@oslomet.no 
Mildrid Bjerke. Renegotiating Aesthetic Disinterest for the Literature Classroom.

an instrumental rationality that relies on being internalised by individuals in their patterns of behaviour and thought, individualising responsibilities for welfare and education in an increasingly privatised and globalised world. Instrumentalism is experienced not simply as a disciplinary imposition, but as a personal moral imperative. I am interested, primarily, in the influence of the tension between this ethos and the values of literary aesthetics on literary pedagogy in UK education. ${ }^{2}$ I will argue that the way in which the neoliberal ethos has permeated educational settings creates a need for a reconceptualised notion of aesthetic disinterest, without which we will struggle to coherently argue for alternative conceptions of the value of education, especially arts and humanities education.

Aesthetic 'disinterestedness', a concept with its origins in the philosophy of Immanuel Kant, can be understood as the idea that aesthetic appreciation is a mode of experience or judgement that lacks function or purpose, that is not targeted at any particular goal in an instrumental manner. The aesthetic is thereby contrasted with other, 'interested' modes of cognition, which involve desires, aims or purposes. In English literary studies in the UK, the concept of aesthetic disinterest has been fundamentally discredited, largely through the influence of critical theory and cultural studies, due to its purportedly reactionary and exclusive political connotations. However, typical statements about the value of the humanities often effectively, but perhaps unwittingly, challenge this seeming paradigmatic shift within literary criticism and theory.

As this paper will argue, such contradictions, unwitting or otherwise, indicate a need for a reconceptualised notion of disinterest which addresses the problems associated with the traditional aesthetic, and which can thus function both as anti-instrumental and as socially inclusive. In attempting to conceptualise this need, parts of the discussion will be aided by the work of literary theorists George Levine and John Guillory. I hope to show that reviving the concept of disinterest would help facilitate a renegotiation of the literature classroom as a space for genuine aesthetic experience and non-instrumental discussion.

\footnotetext{
2 The particular, if largely implicit, context for the discussion is literary pedagogy in UK education, ranging from primary to tertiary education, as the particular conceptual problem treated in this paper (which arises out of the clash between literary criticism in the British tradition and post-Thatcher political development) has implications across the board.
} 
Mildrid Bjerke. Renegotiating Aesthetic Disinterest for the Literature Classroom.

\section{Disinterest and utility}

Let us begin by briefly considering three lines from the penultimate stanza of the Romantic poet William Wordsworth's poem 'The Tables Turned', written in 1798.

Our meddling intellect

Misshapes the beauteous forms of things -

We murder to dissect.

(Wordsworth, 2013).

Here, Wordsworth takes the human intellect to be 'meddling', misshaping 'the beauteous forms of things'. The poem is an archetypal presentation of the idea that intellectual analysis snuffs out the life of the beautiful object. The idea of 'dissection' suggests a purposeful and interested scientific intervention. The cool head of science and reason stops dead the warm heart of art and beauty.

Today, there is a widespread, but I would argue misguided, popular notion that the pleasure of a literary artwork cannot survive analysis. All of us who take an interest in the analysis of literary works have heard a thousand times - from frustrated friends, family and students - that our attempts to delve into the mechanics and dynamics of the aesthetic functioning of the work are somehow 'breaking' it, undermining this very functioning. This common notion, which has its roots in eighteenth-century Romanticism, complicates and hinders literary study, especially in school settings where analysis should be central to literary pedagogy. Even today, the mainstream conception of literary culture involves what literature scholar and educationist Gerald Graff describes as the 'belief that to analyze a literary work or otherwise "intellectualize" about it is to spoil the pleasure of reading' (Graff, 2007) In effect, this conflicted notion renders any kind of codification of the literary - of the kind necessary for aesthetic norms to be explicitly taught rather than implicitly socialised innately suspect.

I will return to this complex of ideas below. However, it is pertinent to point out at this stage in the argument that this problem does not merely arise out of a popular notion, but has its roots in a fundamental conflict within literary studies as a discipline.

Elsewhere I have traced this problem through a history of English literary pedagogy and criticism in the liberal humanist vein, starting with Victorian man of letters and school inspector Matthew Arnold and through the work of F.R. Leavis, Q.D. Leavis and I.A. Richards at the University of Cambridge in the 1920s and 30s (Bjerke, 2015). It will, however, be useful to rehearse some of these ideas here. 
Mildrid Bjerke. Renegotiating Aesthetic Disinterest for the Literature Classroom.

Following English teacher and literary theorist Carol Atherton, I call the conflicted relationship between a disinterested aesthetic experience and pedagogical codification a central 'disciplinary anxiety' within English literary studies (Atherton, 2005). This describes the fundamental conflict between the necessarily interested and targeted character of pedagogy and the ideals of disinterested literary reading. In other words, there is a troublesome relationship between the practical and the aesthetic.

While this tension comes to its fullest expression in Romanticism, the building blocks of the problem emerge from the aesthetics of the eighteenth-century German philosopher, Immanuel Kant. In Critique of the Power of Judgement (2001 [1790]), Kant describes the judgement of beauty as disinterested. For Kant, disinterest suggests the absence of any individual interest or desire and is thus divorced from the sphere of practical utility. Such a purity from worldly matters is conceived by Kant as a prerequisite for the so-called subjective universality of aesthetic experience. In other words, whilst any aesthetic experience is necessarily subjective insofar as it takes place within an individual, that experience nonetheless represents a necessary response to beauty which transcends the interests of the individual, and is thus at the same time subjective and universal. The Kantian ideal of subjective universality in disinterested aesthetic experience thus sets up an opposition between the disinterested and the practical, and consequently the aesthetic and the practical, the reception of which has permeated thinking about literary artworks and the ways in which their aesthetic value/impact is seen to transcend time and place.

Indeed, the connection between these Kantian ideas and the discipline of English literary studies in particular, finds expression in one of the foundational moments of the discipline as a school subject. Matthew Arnold's social project of bringing literary refinement to the British state school has its conceptual heritage in the German postKantian idealist tradition of aesthetic education, in which the individual's Bildung is an ongoing disinterested process of self-cultivation through aesthetic appreciation, the humanising character of which ensures a greater social good through the disinterested functioning of a collective democracy. The most well-known account of this theory, which holds that the aesthetic experience of 'culture' is the key to that disinterested stance, is given by Friedrich Schiller in his On the Aesthetic Education of Man (1994 [1794]), and reworked in the context of a British Romantic tradition by Samuel Taylor Coleridge in his theories on cultivation (Coleridge, 1972, 1976). Arnold's use of these ideas is associated with what literary scholar Chris Baldick aptly calls the 'social mission of English criticism', which has been integral to the formation 
Mildrid Bjerke. Renegotiating Aesthetic Disinterest for the Literature Classroom.

of the discipline of English literature (Baldick, 1983). If, for Arnold, there was a need for such a social mission, this was due to a prevailing atmosphere of crisis in his society engendered by the decline of traditional religious faith in the face of a rising confidence in science, as well as the growing pains of an expanding middle class and the effect on the character of British society of this class's 'vulgar' material concerns. This crisis is associated by Arnold with the clash between interested instrumental forces, associated with civilisation, and disinterested culture. ${ }^{3}$

At Cambridge in the 1920s, I.A. Richards invented the practical criticism method as a response to this conceptual heritage. Richards and others, notably the Leavises and other members of the Scrutiny movement a decade or so later, saw developments in publishing and advertising for the masses as a threat to serious and disinterested reading (Rchards, 1930; Leavis, 1930; Leavis, 1939. See also: Baldick, 1979, Hilliard, 2012). The teaching method of practical criticism sought to harness the purity of a disinterested response to poetry by way of an explicit lack of scaffolding or obvious codification in giving the student an entirely decontextualized piece of writing to respond to purely 'aesthetically'. The method has had a lasting influence on how we think about literature and the ways in which its aesthetic effects can, or perhaps cannot, be taught and codified, as well as how one gains access to or ownership of those aesthetic responses that are typically viewed as legitimately literary. ${ }^{4}$

\section{Codifying aesthetic norms}

As I have indicated above, an immediate problem arises out of this notion of aesthetic appreciation as disinterested, namely that it seems to render aesthetic

\footnotetext{
${ }^{3}$ Kant is the first to make the distinction between culture and civilisation in 'Idea for a Universal History with a Cosmopolitan Purpose', published in 1784. For Kant, culture is tied up with morality insofar as both morality and culture concern the internal condition of the individual. Civilisation, on the other hand, does not share in this concern (Kant, 1991, 41-53). For more on the distinction between culture and civilisation, see (Williams, 1958, xvi; Eagleton, 2000, 9-13; Kooy, 2002, 158).

${ }^{4}$ Practical criticism is still widely used today, if perhaps in a slightly different form. The following citation is taken from the University of Cambridge's web pages: 'Practical criticism today is more usually treated as an ancillary skill rather than the foundation of a critical method. It is a part of many examinations in literature at almost all levels, and is used to test students' responsiveness to what they read, as well as their knowledge of verse forms and of the technical language for describing the way poems create their effects'. https://www.english.cam.ac.uk/classroom/pracrit.htm
} 
Mildrid Bjerke. Renegotiating Aesthetic Disinterest for the Literature Classroom.

appreciation 'unteachable', especially for students who have not been pre-socialised into high culture. Codifying the norms governing literary appreciation and criticism becomes impossible without dismantling, and consequently disabling, those norms by making them explicit. Indeed, the ideal of disinterest, historically speaking, has led to a general obfuscation of what is required of the literature student in learning the correct disciplinary codes.

This has contributed to the exclusion of less privileged students along class lines. An influential sociological description of this classroom conflict between a disinterested aesthetic stance and educational codification is provided by Pierre Bourdieu in his 1979 work, Distinction. Here, the appropriation of legitimate culture through cultural capital and social background is favoured over the instrumental appropriation of culture via pedagogy, 'since even within the educational system it devalues scholarly knowledge and interpretation as "scholastic" or even "pedantic" in favour of direct experience and simple delight' (Bourdieu, 1996, p. 2). Through the ideological status of high culture, aesthetic objects are given the power to impose the norms of their own perception, tacitly defining 'as the only legitimate mode of perception the one which brings into play a certain disposition and a certain competence', meaning that 'all agents, whether they like it or not, whether or not they have the means of conforming to them, find themselves objectively measured by those norms' (Bourdieu, 1996, p. 28). Whilst those who have been socialised into the required cultural code too have learnt that code through more or less observably practical channels, the mastery of it, according to Bourdieu, is acquired 'through an implicit learning analogous to that which makes it possible to recognize familiar faces without explicit rules or criteria - and it generally remains at a practical level', the criteria of which 'usually remain implicit' (Bourdieu, 1996, p. 4). Similarly, in academe, any instrumental tendency in humanist literary pedagogy is seen by many as extrinsic to - and as an imposition upon - literature. As Graff notes, the university tradition has tended to view literature as 'self-interpreting as long as it remained an expression of humanism' (Graff, 2007, 9). This denial of the instrumentality of literary pedagogy involves the idea that 'salvation can be achieved if only the great literary works can be freed from the institutional and professional encumbrances which come between students or laymen and the potency of the work itself' (Graff, 2007, p. 10).

Insofar as not all students possess the kind of cultural capital of which Bourdieu speaks, teaching literary aesthetics requires explicit codification of implicit norms in order to render the latter explicit and thus explicable. The codification required by 
Mildrid Bjerke. Renegotiating Aesthetic Disinterest for the Literature Classroom.

literary pedagogy is a kind of analysis, necessitated by the practical end of teaching a murdering to dissect. As Wordsworth's poem continues:

Enough of Science and of Art;

Close up those barren leaves;

Come forth, and bring with you a heart

That watches and receives.

(Wordsworth, 2013, p. 118)

Here, the warm heart of art and beauty has overcome the cool head of science. For this kind of aesthetic, teaching must always be impossible: conceptually superfluous and disruptive, whilst at the same time entirely necessary for the continued dissemination of this conceptual heritage.

The crux of the matter is that disinterest can never be purely disinterested, but requires a certain amount of instrumentality, or interest, to bring it about. We teach, read, and write about literature in determinate, codified, and discipline-specific 'scientific' ways. At the same time, we are aware that codification is at odds with this central fundamental assumption within the discipline linked to the idea that literary appreciation should be divorced from utility and interest.

\section{The demise of disinterest in aesthetic theory}

As we have seen, the Kantian-Romantic notion of an opposition between the practical and the aesthetic creates problems for our ability to conceptualise how aesthetic and literary appreciation can be taught. However, this has until recently seemed to be an issue that literary educators can avoid, due to the decline of the notion of disinterest in literary and aesthetic theory. Indeed, it is the impossibility of a universally accessible aesthetic that has discredited the traditional aesthetic in literary theory.

In the decades following the 1960s, literary studies underwent a paradigm shift away from liberal-humanist aesthetic ideology. This change was brought about by various branches of aesthetic theory, often informed by leftist political frameworks and critical theory - typically grouped under the umbrella term 'Theory' - and occasioned a depreciation of the concept of the aesthetic and of the traditionally accompanying notion of disinterest. The liberal humanist aesthetic in its various inflections came to be discredited by the new practitioners of Theory due to its socially exclusive approach to education and art appreciation. As pointed out by literary scholars and theorists Jane Elliott and Derek Attridge, the 'various intellectual movements that 
Mildrid Bjerke. Renegotiating Aesthetic Disinterest for the Literature Classroom.

went under the banner of "Theory" all participated in one way or another in the critique of the aesthetic, exposing the manner in which it made illegitimate claims to objectivity, transcendence and universality while in fact endorsing particular, historically-determined, structures of dominance' (Elliott \& Attridge, 2011, p. 11). The work of these theoretical movements was indeed commendable in that it spoke to the necessity of opening up literary and arts education to a larger educational demographic.

In the heyday of 'Theory', however, the deconstruction of the liberal humanist aesthetic did not necessarily imply a dismissal of or hostility towards high art: 'Derrida, Blanchot, Adorno, Kristeva, Lacan, Lyotard and Barthes - to go no further all made powerful claims for the value of artistic practices, and did so while sharing the widespread scepticism regarding the pretensions to objectivity and universalism of the traditional notion of the aesthetic' (Elliott \& Attridge, 2011, p. 11). However, this picture was to change quite dramatically in the 1990s with the development of cultural studies and New Historicism, when 'the distinction between art (especially elite art) and other cultural practices increasingly became the target of critique, and even a deconstructive privileging of the work of art became suspect' (Elliott \& Attridge, 2011, p. 11). Whilst, since the 1990s, several attempts have been made to re-evaluate the Kantian aesthetic, (Gasché, 2003, Loesberg, 2005. See also Levine, 2001, Guillory, 1994) no 'single school of aesthetic theory has arisen to replace the discredited view of the world of art as autonomous, transcendent, detached from the messy business of social and political life and susceptible of disinterested, objective judgement' (Elliott \& Attridge, 2011, p. 11).

\section{Disinterest and neoliberalism in the literature classroom}

However, declarations of the death of the disinterested aesthetic would seem to have been premature. Whilst the concept of disinterest, and the aesthetic as such, have in the view of many theorists and practitioners become antiquated and/or superfluous, these concepts are nonetheless habitually brought out in defence of the arts and humanities in the face of neoliberal political and economic pressures. Humanities scholars often defend their work through generalised, and often strikingly oldfashioned, appeals to democracy and aesthetic education. Such responses often recall the rhetoric of disinterest: here, the value of humanities disciplines tends to be viewed as unbiased by instrumental concerns, but invariably, nonetheless, as useful 
Mildrid Bjerke. Renegotiating Aesthetic Disinterest for the Literature Classroom.

at the levels of the personal and the social. ${ }^{5}$ As Helen Small writes, 'the arguments going on today about the value of the humanities have deep roots in the efforts of many of the best-remembered Victorian writers to articulate, for their period, the value of a "liberal" education and culture'. The Victorian period, writes Small, is when 'one sees emerging the now familiar pressure to justify expenditure on educating students in the humanities in the face of resistance from many political economists' (Small, 2013, p. 7).

One important factor in the dissemination of neoliberal ideology throughout the social sphere has been its public pedagogical function, to borrow a phrase from literary and political theorist Sophia A. McClennen: 'the precise ways in which it teaches individuals to live, to understand their place in the world, and to imagine the future' (McClennen, 2010, p. 205). The noted social scientist David Harvey, too, picks up on this tendency of neoliberalism to spread beyond the strictly economic sphere. He describes the way in which the market, according to neoliberal ideology, is 'presumed to work as an appropriate guide —an ethic_for all human action' (Harvey 2005, p. 165).

This ethic or ethos is not, however, simply a public affair, but becomes integrated into the habits of thoughts and action of individuals. This aspect of neoliberalism is highlighted in Foucault's concept of rational governmentality, which provides a useful approach to understanding how the neoliberal ethos achieves its hegemonic status and expands beyond the economic sphere (e. g. Foucault, 1982). ${ }^{6}$ Foucault's

\footnotetext{
${ }^{5}$ The debate about the economic, social, and public value(s) of the humanities is currently taking place in a wide range of media from academic journals to Twitter, and is much too extensive to be comprehensively reviewed here. A useful and succinct list of widely held beliefs about the humanities (in the American context) is offered by Judith Butler: 'the humanities have intrinsic value; the humanities are useless, and that is their value; public intellectuals exemplify the value of the humanities for public life; the humanities offer certain kinds of skill development that are important for economic mobility; the humanities offer certain kinds of literacy that are indispensable to citizenship; and finally, the humanities offer a critical perspective on values that can actively engage the contemporary metrics of value by which the humanities themselves are weakened, if not destroyed' (Butler, 2014, p. 27). For a comprehensive account of the most widely used arguments on behalf of the humanities (focusing on both British and American debates), see (Small, 2013).

${ }^{6}$ The concept remains fragmentary in Foucault's work, but has been developed usefully in the field of cultural studies. See (Rose, 1999, 1996; Gordon, 1991).
} 
Mildrid Bjerke. Renegotiating Aesthetic Disinterest for the Literature Classroom.

emphasis on mentality in governing reflects his contention that power and ideas are not separate phenomena (Brown, 2003). Neoliberalism requires both government and self-government. As such, neoliberalism's destabilisation of the welfare state and redescription of welfare as a set of individualised responsibilities rather than a matter of social solidarity relies on the way in which neoliberal discourse comes to permeate the attitudes of individuals towards individualised duties. In other words, neoliberalism governs both from above and from within the habituated thinking of individuals.

So whilst neoliberalised education's use of standardised testing and demands for calculable results follow an economic logic which is not compatible with the spirit of the humanities, the devaluation of the arts and humanities is not simply administered, in this way, from above through top-down policies and funding. Because of the way in which neoliberalism operates as an ethos, this is also a matter of an ideology coming to be internalised by students eager to advance their human, rather than cultural, capital in an increasingly globalised and market-driven world. Historian and sociologist of literature John Guillory holds, for example, that in recent decades the status of cultural capital itself has changed through the expansion of the professionalmanagerial class and its instrumentalised values. As Guillory notes, the 'professionalmanagerial class has made the correct assessment that, so far as its future profit is concerned, the reading of great works is not worth the investment of very much time or money' (Guillory, 1994, p. 46).

How should advocates of the value of aesthetic education respond to this pervasive instrumentalising ethos? It may seem outmoded that the humanities, characterised by constant critical revision and rethinking of dogma, should return to metaphysical truths about Man and Art stemming from the German Enlightenment when called upon by new management logics to justify themselves. Collini (2012) caricatures the excessive estimation of the university and its humanising impulse: 'the same excess lurks in even the best-intentioned defences of universities today, to the point where the sceptic begins to wonder at the implication that reflective or analytical capacities can only arise and survive as the result of a successful UCAS application' (Collini, 2012, p. 52). Collini holds that arguments for the social value of literature and the humanities often come 'perilously close to appearing to suggest that respect for, and tolerance of, other people is only likely to be achieved by those who have taken some kind of "great books" course at college' (p. 95).

However, it is my contention that this retreat to Victorian disinterested ideals provides a valuable insight, namely that some notion of disinterest is still active within literary 
Mildrid Bjerke. Renegotiating Aesthetic Disinterest for the Literature Classroom.

studies and other humanities disciplines. Whereas the liberal humanist aesthetic, at least at the level of the conceptual, worked against the forces of political instrumentalism, this role now needs to be filled by a new, updated, form of resistance. As we have seen, however, the project of salvaging 'disinterest', is easily undermined by its theoretically informed critique for its socially regressive political connotations.

\section{Reconstructing disinterest}

I ask, therefore, can the concept of disinterest be mobilised within literary pedagogy to create a truly reflective space where aesthetic experience can, at least temporarily, stave off quantification and facilitate social inclusion and understanding? It is my claim that the concept of disinterest need not be discredited if it can be disassociated from the demand for purity within liberal humanist aesthetic discourse, granting its necessary complicity with certain less problematic forms of interestedness, in particular those pertaining to pedagogy.

Paying attention to the demands of pedagogy holds the key to exposing the flaws in an overly binary opposition between interest and disinterest. If the opposition between the aesthetic and the practical is genuinely irreconcilable, then disinterested aesthetic appreciation cannot be taught. This might seem to be grounds to reject the notion of disinterest, but it can also provide a key to preserving some notion of disinterest. Thinking through the conditions for a disinterested aesthetic education provides us with a concrete frame within which to progress beyond the Romantic idea of an irreconcilable opposition between interest and disinterest, towards the idea of a necessary complicity between interest and disinterest.

In 2010, the philosopher Martha Nussbaum wrote that an 'assault' on the arts and humanities 'is currently taking place all over the world' (Nussbaum, 2010, p. 24). Nussbaum notes that curricular content has shifted correspondingly 'away from the material that focuses on enlivening imagination and training the critical faculties toward material that is directly relevant to test preparation' (p. 134). This shift in content has brought with it 'an even more baneful shift in pedagogy: away from teaching that seeks to promote questioning and individual responsibility toward forcefeeding for good exam results' (p. 134). Here, then, there is room for a vindication of a less instrumental, more 'disinterested', literary pedagogy which permits a greater measure of imaginative and critical responses. 
Mildrid Bjerke. Renegotiating Aesthetic Disinterest for the Literature Classroom.

Literary theorists George Levine and John Guillory provide us with useful conceptual resources in thinking through this revitalisation of aesthetic experience as disinterested.

Levine argues that all human beings have the capacity to respond to certain features of the world around us by having experiences of a kind that we would term 'aesthetic' experiences. Thus, he holds, 'the tendency towards the aesthetic is likely to be universal to human nature'. Crucially, however, 'its particular manifestations must be determinedly cultural' (Levine, 2001, p. 922). The universality of the aesthetic impulse need not be understood to negate the multiplicity of its particular cultural expressions. Indeed, it is this necessary cultural context that renders problematic traditional notions of the 'purity' of aesthetic experience; but the key to saving some notion of disinterest is precisely to extricate it from this 'purity' that renders mysterious how disinterest can be cultivated at all.

Similarly, Guillory (1994) seeks to uphold an idea of the aesthetic compatible with a reworked conception of its disinterestedness, by problematising the supposed 'purity' of the Kantian-Romantic idea of disinterestedness (Guillory, 1994, p. 327). The possibility of an 'impure' disinterest has been obscured, holds Guillory, by a political critique of the aesthetic as reactionary which poses "the "aesthetic" and the "political" as the discursive antithesis of current critical thought', thus enjoining 'a choice between them' (273). But, this dichotomy is a false one, engendered by the historical determinacy of any given expression of the aesthetic. Insofar as the aesthetic cannot be disengaged from particular, historically determinate discourses, it is liable, as with any discourse, to be criticised as 'the vehicle of ideology, that is to say, an arena of social struggle' (p. 282). Guillory's point, like Levine's, is that the aesthetic as a universal human impulse cannot be reduced to its multitudinous historical manifestations, although it cannot be disentangled from them either.

If we follow Levine and Guillory in reconceiving aesthetic disinterest as universal yet always embroiled in a cultural and historical context, a distinctive sphere of human experience but not an otherworldly one, then we can understand how 'interested' uses of art objects in pedagogy need not compromise the value of aesthetic experience in itself. It is the claim to a pure and objective disinterest that refuses reconciliation with instrumental pedagogy.

In seeking to resolve this tension by demystifying the liberal humanist conception of disinterest, much re-evaluation of aesthetic concepts threatens to throw the baby out with the bathwater. Because it fails to locate the problem with the traditional 
Mildrid Bjerke. Renegotiating Aesthetic Disinterest for the Literature Classroom.

conception of disinterest in its claim to purity and objectivity, such re-evaluation often targets not just liberal humanist elitism, but any conception of the aesthetic as, in Levine's words, 'distinctly different from those worldly actions that constitute the practical texture of our lives' (Levine, 2001, p. 926). It is my contention that this misapprehension opens the door to instrumental rationalities such as the neoliberal ethos, which seek to deny, or at least deny the value of, dimensions of human life and experience that transcend this 'practical texture'. In my view, conceptions of the aesthetic that do not make some space for disinterestedness struggle to account for the special significance of the aesthetic.

It is my contention, therefore, that we can and must conceive of a mixed, or contingent, conception of disinterest - one that is compatible with the purposes of the political left in a project of resistance, within pedagogy, against rationalising and neoliberal interests, by functioning as a critical element in society. Thus relieved of its obligations towards purity and objectivity, the notion of contingent disinterest in aesthetic appreciation can help create, in Levine's words, 'a public, communal space in which the deepest values of the culture are recognized as more than private precisely the condition that allows for a release from self-interest' (Levine, 2001, p. 927). Such a conception, always contingent upon several different contexts, could provide a healthy counterweight to the reductive and blinkered influence of neoliberal instrumentality on education.

Thus reconceptualised, disinterest provides a space for imaginative aesthetic responses which removes some of the demand for supposed 'correct' answers. This renewed attention to literary reading as a relatively 'free' form of the play of the imagination also empowers students with a critical perspective upon the neoliberal ethos that urges them to approach literary reading in terms of calculated rationalising predictions about assessment.

\section{Conclusion}

This paper has argued that we need some notion of the disinterested in aesthetics in order not to lose the valuable idea of literary and aesthetic experience as a space for 'free' reflection. As the paper has shown, the idea of disinterest as a bulwark against the overreach of instrumental reason is more tenacious than its critics may have given it credit for. The concept of the disinterested aesthetic, as it has been received and operationalised in English literary studies, encounters serious problems in the transition from philosophical descriptions of a subjective but universally necessary aesthetic experience to educational practice - particularly in the context 'mass' 
Mildrid Bjerke. Renegotiating Aesthetic Disinterest for the Literature Classroom.

education -, and has therefore, rightly, been discredited. However, I have argued that the re-emergence of seemingly outmoded forms of argumentation in defences of the humanities indicates that the concept of disinterest still has important work to do in our thinking about the value of literature and the arts and of literary and arts education. The presence of this remnant of a liberal humanist aesthetics, which is broadly seen to have been already dismantled, is evidence of the need for a reconceptualised notion of disinterest better suited for its purpose: acting as a buffer against the influence of the neoliberal ethos in literary education.

It is my hope that such a conception of disinterest - redescribed as impure and socially inclusive - could help protect what I believe to be the core values of literary pedagogy: creating a reflective space for aesthetic reactions, with reduced pressures on the individual to make calculating decisions about her future.

\section{About the author}

Mildrid H. A. Bjerke is associate professor of English in the Department of Primary and Secondary Teacher Education at Oslo Metropolitan University. Bjerke holds a $\mathrm{PhD}$ in English Literature from the University of York (UK), with a thesis on the history of the literature study guide and its relation to foundational tensions in English literature as a university discipline and school subject in the UK. Her research focuses on questions relating to literary value and utility, aesthetic experience and education, and the value of the humanities.

\section{References}

Atherton, C. (2005). Defining Literary Criticism: Scholarship, Authority and the Possession of Literary Knowledge, 1880-2002. Basingstoke: Palgrave Macmillan. https://doi.org/10.1057/9780230501072

Baldick, C. (1983). The Social Mission of English Criticism: 1848-1932. Oxford: Clarendon Press.

Bjerke, M. H. A. (2015). Interested Disinterest: The Development of the Literature Study Guide. [PhD dissertation, University of York]. http://etheses.whiterose.ac.uk/11179/

Bourdieu, P. (1996). Distinction: A Social Critique of the Judgement of Taste. Cambridge Massachusetts: Harvard University Press.

Brown, W. (2003). Neoliberalism and the End of Liberal Democracy. Theory and Event 7(1). https://doi.org/10.1353/tae.2003.0020 
Mildrid Bjerke. Renegotiating Aesthetic Disinterest for the Literature Classroom.

Butler, J. (2014). Ordinary, Incredulous. In P. Brooks \& H. Jewett (Eds.), The Humanities and Public Life (15-37). New York: Fordham University Press. https://doi.org/10.5422/fordham/9780823257041.003.0002

Coleridge, S. T. (1972). Lay Sermons. Edited by R. J. White. London and Princeton, NJ: Princeton University Press.

Coleridge, S. T. (1976). On the Constitution of Church and State. Edited by J. Colmer. London and Princeton, NJ: Princeton University Press.

Collini, S. (2012). What Are Universities For? London: Penguin.

Eagleton, T. (2000). The Idea of Culture. Oxford: Blackwell.

Elliott, J. \& Attridge, D. (2011). Introduction: Theory's Nine Lives. In J. Elliott \& D. Attridge (Eds.), Theory After Theory (p. 1-15). London: Routledge. https://doi.org/10.4324/9780203831168

Foucault, M. (1982). The Subject and Power. In H. Dreyfus \& P. Rabinow (Eds.), Michel Foucault: Beyond Structuralism and Hermeneutics (p. 208-226). Brighton: Harvester.

Gasché, R. (2003). The Idea of Form. Rethinking Kant's Aesthetics. Stanford, CA: Stanford University Press.

Gordon, C. (1991). Govermental Rationality: An Introduction. In G. Burchell, C. Gordon and P. Miller (Eds.), The Foucault Effect (p. 1-52). Chicago: University of Chicago Press.

Graff, G. (2007). Professing Literature: An Institutional History. Chicago: Chicago University Press. https://doi.org/10.7208/chicago/9780226305257.001.0001

Guillory, J. (1994). Cultural Capital: The Problem of Literary Canon Formation. Chicago: University of Chicago Press. https://doi.org/10.7208/chicago/9780226310015.001.0001

Harvey, D. (2005). A Brief History of Neoliberalism. Oxford: Oxford University Press. https://doi.org/10.1093/oso/9780199283262.001.0001

Hilliard, C. (2012). English as a Vocation: The 'Scrutiny' Movement. Oxford: Oxford University Press. https://doi.org/10.1093/acprof:oso/9780199695171.001.0001

Kooy, M. J. (2002). Coleridge, Schiller and Aesthetic Education. Basingstoke: Palgrave Macmillan. https://doi.org/10.1057/9780230596788

Kant, I. (1991). Idea for a Universal History with a Cosmopolitan Purpose, In H. S. Reiss (Ed.) Kant: Political Writings, (p. 41-53). Cambridge: Cambridge University Press. https://doi.org/10.1017/CBO9780511809620.004

Kant, I. (2001). Critique of the Power of Judgement. Edited by P. Guyer. Cambridge: Cambridge University Press.

Leavis, F. R. (1930). Mass Civilisation and Minority Culture. Cambridge: Minority Press. 
Mildrid Bjerke. Renegotiating Aesthetic Disinterest for the Literature Classroom.

Leavis, F. R. \& Thompson, D. (1964). Culture and Environment: The Training of Critical Awareness. London: Chatto \& Windus.

Leavis, Q. D. (1939). Fiction and the Reading Public. London: Chatto \& Windus. Levine, G. (2001). Saving Disinterest: Aesthetics, Contingency, and Mixed Conditions. New Literary History 32(4), 907-31. https://doi.org/10.1353/nlh.2001.0054

Loesberg, J. A. (2005). Return to Aesthetics. Autonomy, Indifference and Postmodernism. Stanford, CA: Stanford University Press.

McClennen, S. A. (2010). Neoliberalism and the Crisis of Intellectual Engagement. In E. J. Carvalho and D. B. Downing (Eds.) Academic Freedom in the Post-9/11 Era (p. 203-213). New York: Palgrave Macmmillan.

https://doi.org/10.1057/9780230117297 11

Mulhern, F. (1979). The Moment of Scrutiny. London: New Left Books.

Nussbaum, M. (2010). Not for Profit: Why Democracy Needs the Humanities. Princeton: Princeton University Press.

Richards, I. A. (1930). Practical Criticism: A Study of Literary Judgement. London: Kegan Paul, Trench and Trubner.

Rose, N. (1996). Governing “Advanced” Liberal Democracies. In A. Barry, T. Osborne \& N. Rose (Eds.), Foucault and Political Reason: Liberalism, NeoLiberalism and Rationalities of Government, (p. 37-64). Chicago: University of Chicago Press.

Rose, N. (1999). Governing the Soul: The Shaping of the Private Self. London: Free Association Books.

Schiller, F. (1994). On the Aesthetic Education of Man, in a Series of Letters.

Translated by Reginald Snell. Bristol: Thoemmes P. https://doi.org/10.5040/9781350244139

Small, H. (2013). The Value of the Humanities. Oxford: Oxford University Press. https://doi.org/10.1093/acprof:oso/9780199683864.001.0001

The University of Cambridge. (2020). Introduction to Practical Criticism. Accessed 19th February 2020. https://www.english.cam.ac.uk/classroom/pracrit.htm. Williams, R. (1958). Culture and Society, 1780 - 1950. London: Chatto \& Windus. Wordsworth, W. (2013). 'The Tables Turned.' In William Wordsworth and Samuel Taylor Coleridge. Eds: D. Porter \& M. Gamer. Lyrical Ballads: 1798 and 1802, (p. 117-118). Oxford: Oxford University Press. 